\title{
Knowledge and self-reported confidence in antimicrobial stewardship programme among final year pharmacy undergraduate students in Malaysia and Nigeria
}

\author{
Usman Abubakar ${ }^{1}$ (D) , Abubakar Sha'aban ${ }^{1,2}$ (D) Mustapha Mohammed ${ }^{1,2}$ (D) , Haseeb T. Muhammad ${ }^{1}$ (D), \\ Syed Azhar Syed Sulaiman ${ }^{1,3}$ (D), Omalhassan Amir ${ }^{4}$ iD \\ ${ }^{1}$ Discipline Clinical Pharmacy, School of Pharmaceutical Sciences, Universiti Sains Malaysia, Pulau Pinang, Malaysia \\ 2Department of Clinical Pharmacy, Faculty of Pharmaceutical Sciences, Ahmadu Bello University, Zaria, Nigeria \\ ${ }^{3}$ Advanced Medical and Dental Institute, Universiti Sains Malaysia, Penang, Malaysia \\ ${ }^{4}$ Department of Clinical Pharmacy, International University of Africa, Khartoum, Sudan
}

\section{Keywords}

Antibiotic resistance

Antimicrobial stewardship

Antimicrobial therapy

Malaysia

Nigeria

Pharmacy students

\section{Correspondence}

Usman Abubakar

Discipline of Clinical Pharmacy

School of Pharmaceutical Sciences

Universiti Sains Malaysia

Pulau Pinang 11800

Malaysia

pharmumma2@gmail.com

\begin{abstract}
Objective: This study evaluated the knowledge and self-reported confidence of antimicrobial stewardship (AMS) among pharmacy students in Malaysia and Nigeria. Methods: A cross-sectional study was conducted among final year undergraduate pharmacy students in a university from both Nigeria and Malaysia using a 59-item online questionnaire. Results: A total of 150 final year undergraduate pharmacy students completed the questionnaire. Exposure to infectious diseases clerkship was higher among the Malaysian students (78.2\% versus $25.4 \% ; p<0.001)$. Overall, the knowledge score for antibiotic resistance and AMS were comparable $(6.2 \pm 1.5$ and $3.6 \pm 1.2$, respectively versus $5.9 \pm 1.6$ and $3.3 \pm 1.3$ ). The knowledge of antibiotic therapy was higher among the Malaysian students $(5.4 \pm 1.8$ versus $4.2 \pm 1.8 ; p<$ 0.001 ) while self-reported confidence to participate in AMS was higher among the Nigerian students (median 48.0, IQR $26-75$ versus median 36.5, IQR $15-75 ; p<$ 0.001). Conclusions: Pharmacy students in Malaysia and Nigeria have appreciable knowledge of antibiotic resistance, antibiotic therapy and AMS. More training on topics is recommended to improve the skills and competency of future pharmacists to participate in AMS.
\end{abstract}

\section{Introduction}

Antimicrobial resistance has emerged as a threat to global public health with an alarming increasing prevalence in recent years (World Health Organization, 2014). Antimicrobial resistance has been associated with morbidity, mortality, and economic cost in the health sector ( European Center for Disease Prevention and Control, 2009; Centers for Disease Control and Prevention, 2013). The lack of new antimicrobials in the development pipeline has amplified the problem of antimicrobial resistance (World Health Organization,
2014). The inappropriate use of antimicrobials in both hospital and community settings is one of the drivers of antimicrobial resistance (World Health Organization, 2014). Available evidence shows that $20 \%$ to $50 \%$ of antimicrobial prescriptions in the hospital are inappropriate (Centers for Disease Control and Prevention, 2013). In community settings, the purchase of antimicrobials without prescription and selfmedication with antimicrobials are common issues. Globally, it is estimated that $62 \%$ of antimicrobials dispensed in community pharmacies have no 
prescription (Auta et al., 2018). These activities contribute to the emergence and spread of antimicrobial resistance.

Antimicrobial stewardship (AMS) is identified as one of the strategies to mitigate against antimicrobial resistance. The goal of AMS is to reduce the misuse of antimicrobials, improve clinical outcomes, and reduce healthcare costs and antimicrobial resistance (CDC, 2014; Pollack \& Srinivasan, 2014; WHO, 2014). A multidisciplinary AMS team, which includes a pharmacist, is considered as a core component of an AMS programme (Wickens et al., 2013; CDC, 2014). Both the Center for Disease Control and Prevention (CDC) and the American Society of Health-System Pharmacists (ASHP) have stated that pharmacists have an important role to play in AMS and infection prevention and control programmes (Ponto, 2010; CDC, 2014). Pharmacists contribute to AMS activities in various ways, including the audit of antimicrobial use with feedback to prescribers, providing empirical antimicrobial guidance, developing formularies and guidelines (Wickens et al., 2013), automatic change and stop orders, therapeutic drug monitoring, dose adjustment, and optimisation, and assuming leadership of AMS programme in healthcare facilities (CDC, 2014; Pollack \& Srinivasan, 2014). Besides, pharmacist-led AMS activities improve the appropriate use of antimicrobials, optimize patient's clinical outcomes, and reduce antimicrobials expenditure (Wang et al., 2015; Brink et al., 2016; Abubakar et al., 2019).

In Malaysia and Nigeria, inappropriate use of antimicrobials in both hospital and community settings have been reported ( Ab Rahman et al., 2016; Abubakar et al., 2019; Abubakar, 2020; Tham et al., 2020). Hospital and community pharmacists, as experts on drugs and drug use, have an opportunity to improve the quality of antimicrobial use among patients through participation in AMS activities. However, studies revealed that lack of training is one of the major barriers that hinder pharmacists' involvement in AMS activities (Rizvi et al., 2018; Weier et al., 2018; Abubakar \& Tangiisuran, 2020), and as a result, AMS training has been recommended for practising pharmacists to build their skills and confidence. The training of future pharmacists is also essential to prepare them for active participation in AMS activities. The background of pharmacy education and practices are quite different between Malaysia and Nigeria. In Malaysia, undergraduate pharmacy students are exposed to experiential learning (hospital clerkship) and are expected to complete rotations in internal medicine, infectious disease, paediatrics and therapeutic drug monitoring before graduation. In Nigeria, undergraduate pharmacy students have lesser experiential learning experience; students go to the wards for a clerkship in the first semester of their final year and are usually attached to one unit only. The rationale of this study was to investigate the influence of exposure to experiential learning, especially infectious disease clerkship, on students' knowledge and self-confidence to participate in antimicrobial stewardship activities. The objective of this study is to assess and compare the knowledge and self-reported confidence in antimicrobial stewardship programmes between final year pharmacy undergraduate students in Malaysia and Nigeria.

\section{Methods}

\section{Study design and settings}

This was a cross-sectional study conducted among final year pharmacy undergraduate students in two universities, one each in Nigeria and Malaysia. Both universities offer a Bachelor of Pharmacy (B. Pharm) degree programme, although the duration of the programme varies between the two schools. Students in Nigeria spend five years while those in Malaysia spend four years to obtain a B. Pharm degree. In both universities, students take mandatory infectious diseases (ID) pharmacotherapy courses, which exposes them to antimicrobial resistance and the principles of antimicrobial therapy. ID clerkship is compulsory for undergraduate pharmacy students in the Malaysian university involved in this study in contrast to the requirement in Nigeria. Currently, there are no postgraduate training opportunities in ID Pharmacy in both countries.

\section{Study population}

The study population included all final year undergraduate pharmacy students in a university from both Nigeria and Malaysia. Only those who agreed to participate in the survey were included. Those who declined to participate and non-final year pharmacy students were excluded. Participation was voluntary, and no incentive was given to students to participate in the survey.

\section{Study questionnaire}

A 59-item questionnaire was developed after the review of the literature. Details of the questionnaire design and validation have been published elsewhere (Abubakar et al., 2020). The questionnaire consists of six sections: demographic (7 items), knowledge of antimicrobials resistance (10 items), knowledge of antimicrobial therapy (10 items), knowledge of antimicrobial stewardship (5 items), perceptions 
regarding antimicrobial resistance (5 items), selfconfidence to accomplish antimicrobial stewardship tasks (15 items) and perception towards antimicrobial stewardship ( 7 items). Knowledge of antimicrobial resistance, antimicrobial therapy, and antimicrobial stewardship was assessed using multiple-choice questions with one best answer. Self-confidence to complete antimicrobial stewardship activities and perceptions regarding antimicrobial resistance were evaluated using a 5-point Likert scale.

\section{Data collection}

The survey was conducted during the first semester of the 2017/2018 academic session. The academic calendar in the schools differed. The data were collected between October and December 2017 in Malaysia and between January and March 2018 in Nigeria. All the final year pharmacy undergraduate students in the two universities were invited to participate in an electronic survey designed to assess their knowledge of antimicrobial resistance, antimicrobial therapy, and antimicrobial stewardship. The hyperlink to the electronic survey was sent to the students through their respective class WhatsApp groups. A reminder was sent to the students every two weeks. The students were advised to avoid multiple submissions. Response to the questionnaire was anonymous, and students were informed through a cover letter attached to the questionnaire that submission of response would be considered as consent to participate in the survey. An approval to conduct the study was obtained from both schools before data collection.

\section{Data analysis}

The data were analysed using IBM SPSS (statistical package for service solutions) Statistics version 23. The data was de-identified before analysis. Categorical and continuous variables were presented as a frequency with percentage and mean with standard deviation, respectively. The responses in the knowledge sections were transformed into scores using 1 and 0 for correct and wrong responses, respectively. The knowledge score was the sum of the correct responses to items in each section. Self-confidence was transformed into scores as follows: 5 to 1 point (extreme confidence to no confidence at all). Differences in knowledge and selfconfidence scores between the two universities were tested using the t-test and Mann-Whitney $U$ test. Association between variables were measured using the Chi-Square tests. A $p$-value that is less than 0.05 was considered to be statistically significant.

\section{Results}

\section{Characteristics of the final year undergraduate pharmacy students}

A total of 150 (87 and 63 in Malaysia and Nigeria, respectively) final year undergraduate pharmacy students completed the questionnaire, with a response rate of $76 \%$ and $53 \%$ from Malaysia and Nigeria, respectively. Overall, $57 \%$ of the respondents were females. Attendance of a course/workshop on the appropriate use of antimicrobial and infectious diseases clerkship was significantly higher among the Malaysian students ( $85.1 \%$ and $78.2 \%$, respectively) compared to the Nigerian students $(68.3 \%$ and $25.4 \%$, respectively). There was no significant difference in attendance of an antimicrobial resistance course/workshop between the two groups. The lecture was the most common source of information about antimicrobials and antimicrobial resistance in both groups. The details of the characteristics of the final year undergraduate pharmacy students are shown in Table I.

Table I: Characteristics of the final year undergraduate pharmacy students

\begin{tabular}{|c|c|c|c|}
\hline \multirow[b]{2}{*}{ Variable } & \multicolumn{2}{|c|}{ Frequency (\%) } & \multirow[b]{2}{*}{$p$-value } \\
\hline & $\begin{array}{l}\text { Nigeria } \\
(n=63)\end{array}$ & $\begin{array}{l}\text { Malaysia } \\
(\mathrm{n}=87)\end{array}$ & \\
\hline \multicolumn{4}{|l|}{ Gender } \\
\hline - Male & $42(66.7)$ & $23(26.4)$ & $<0.001^{*}$ \\
\hline - Female & $21(33.3)$ & $64(73.6)$ & \\
\hline \multicolumn{4}{|l|}{ Source of information } \\
\hline - Lecture & $51(81.0)$ & $39(44.8)$ & $<0.001^{\dagger}$ \\
\hline - Textbook & $8(12.7)$ & $3(3.4)$ & \\
\hline - Journal & $1(1.6)$ & $10(11.5)$ & \\
\hline - Internet & $3(4.8)$ & $26(29.9)$ & \\
\hline - Guideline & $0(0.0)$ & $5(5.7)$ & \\
\hline - Smartphone & $(0.0)$ & $4(4.6)$ & \\
\hline $\begin{array}{l}\text { Attended a workshop/course } \\
\text { on antimicrobial resistance }\end{array}$ & $42(66.7)$ & $58(66.7)$ & $0.052 *$ \\
\hline $\begin{array}{l}\text { Attended a workshop/course } \\
\text { on the appropriate use of } \\
\text { antibiotic }\end{array}$ & $43(68.3)$ & $74(85.1)$ & $0.006 *$ \\
\hline $\begin{array}{l}\text { Attended infectious diseases } \\
\text { clerkship }\end{array}$ & $16(25.4)$ & $68(78.2)$ & $<0.001^{*}$ \\
\hline \multicolumn{4}{|l|}{ Area of interest after graduation } \\
\hline - Academia & $12(19.0)$ & $1(1.1)$ & $<0.001^{\dagger}$ \\
\hline - Community & $20(31.7)$ & $13(14.9)$ & \\
\hline - Hospital & $9(14.3)$ & $52(59.8)$ & \\
\hline - Industrial & $2(3.2)$ & $2(2.3)$ & \\
\hline - Others & $3(4.8)$ & $2(2.3)$ & \\
\hline - Undecided & $6(9.5)$ & $15(17.2)$ & \\
\hline $\begin{array}{l}\text { Career interest in Infectious } \\
\text { Disease pharmacy }\end{array}$ & $24(38.1)$ & $18(20.7)$ & $<0.001^{* *}$ \\
\hline
\end{tabular}




\section{Knowledge and perception towards antimicrobial resistance}

More than two-thirds of the students correctly identified the definition of antimicrobial resistance, mechanisms, and factors that promote the emergence of antimicrobial resistance, as well as interventions used to fight against antimicrobial resistance. However, more than $50 \%$ of the students did not know the factors that promote the spread of antimicrobial resistance and the consequences of antimicrobial resistance. The student in Malaysia demonstrated higher knowledge of the reservoirs of antimicrobial-resistant infections (50.6\%) compared to the Nigerian students (17.5\%), $p<$ 0.001 . Overall, the mean knowledge of antimicrobial resistance was comparable between the two groups; $5.9 \pm 1.6$ out of 10.0 in Nigeria and $6.2 \pm 1.5$ in Malaysia ( $p=0.327)$. Malaysian students showed significantly higher perception scores (median 23.0, IQR 16 - 25) than their Nigerian counterparts (median 22.5, IQR 12 -25). The details of knowledge and perception towards antimicrobial resistance are shown in Table II.

\section{Knowledge of antimicrobial therapy}

There was no significant difference in the knowledge of upper respiratory tract infection (URTI) not requiring an antimicrobial, antimicrobial for Clostridium difficile infection, and antimicrobial use in pregnancy between the two groups. Final year pharmacy students in Malaysia had higher knowledge of diarrhea that has no indication for antimicrobial therapy $(85.1 \%$ versus $50.8 \%, p<0.001)$, antimicrobials with the best activity against anaerobes (56.3\% versus $38.1 \%, p=0.032$ ) and MRSA $(90.8 \%$ versus $39.7 \%, p<0.001)$, an antimicrobial that crosses the blood-brain barrier $(64.4 \%$ versus $47.6 \%, p=0.046)$ and appropriate antimicrobial regimen for surgical antimicrobial prophylaxis for caesarean section (33.3\% versus $9.5 \%, p=0.001$ ) compared to final year students in Nigeria. The Nigerian students demonstrated significantly higher knowledge of appropriate antimicrobials used for uncomplicated UTI (55.6\%) than their Malaysian counterparts (26.4\%). Overall, the Malaysian students had a higher mean knowledge score for appropriate antimicrobial therapy $(5.4 \pm 1.8$ out of 10.0$)$ than the Nigerian students ( $4.2 \pm$ $1.8, p<0.001)$. The details on the knowledge of antimicrobial therapy are shown in Table III.
Table II: Knowledge and perception towards antimicrobial resistance among final year pharmacy students

\begin{tabular}{|c|c|c|c|}
\hline \multirow{2}{*}{$\begin{array}{l}\text { Knowledge of } \\
\text { antimicrobial } \\
\text { resistance }\end{array}$} & \multicolumn{2}{|c|}{ Correct responses (\%) } & \multirow[b]{2}{*}{$\begin{array}{c}p- \\
\text { value }\end{array}$} \\
\hline & $\begin{array}{l}\text { Nigeria } \\
(n=63)\end{array}$ & $\begin{array}{l}\text { Malaysia } \\
(\mathrm{n}=87)\end{array}$ & \\
\hline $\begin{array}{l}\text { Definition of antibiotic } \\
\text { resistance }\end{array}$ & $61(96.8)$ & $84(96.6)$ & $1.000^{\dagger}$ \\
\hline $\begin{array}{l}\text { Recognise a wrong } \\
\text { statement regarding } \\
\text { antibiotic resistance }\end{array}$ & $31(49.2)$ & $22(25.3)$ & $0.003^{*}$ \\
\hline $\begin{array}{l}\text { Identify mechanisms } \\
\text { of antibiotic resistance }\end{array}$ & $59(93.7)$ & $75(86.2)$ & $0.185^{*}$ \\
\hline $\begin{array}{l}\text { Pinpoint an antibiotic } \\
\text { hydrolysed by beta- } \\
\text { lactamase enzyme }\end{array}$ & $49(77.8)$ & $78(89.7)$ & $0.065^{*}$ \\
\hline $\begin{array}{l}\text { Identify reservoirs of } \\
\text { antibiotic resistant } \\
\text { infection }\end{array}$ & $11(17.5)$ & $44(50.6)$ & $<0.001^{*}$ \\
\hline $\begin{array}{l}\text { Identify antibiotic- } \\
\text { resistant-pathogens }\end{array}$ & $31(49.2)$ & $53(60.9)$ & $0.183^{*}$ \\
\hline $\begin{array}{l}\text { Identify factors that } \\
\text { promote the } \\
\text { emergence of } \\
\text { antibiotics resistance }\end{array}$ & $50(79.4)$ & $75(86.2)$ & $0.375^{*}$ \\
\hline $\begin{array}{l}\text { Identify factors that } \\
\text { promote the spread of } \\
\text { antibiotic-resistant } \\
\text { infections }\end{array}$ & $9(14.3)$ & $11(12.6)$ & $0.811^{*}$ \\
\hline $\begin{array}{l}\text { Identify the } \\
\text { consequences of } \\
\text { antibiotic resistant } \\
\text { infection }\end{array}$ & $28(44.4)$ & $36(41.4)$ & $0.740 *$ \\
\hline $\begin{array}{l}\text { Identify intervention } \\
\text { for fighting antibiotic } \\
\text { resistance }\end{array}$ & $45(71.4)$ & $61(70.1)$ & $1.000 *$ \\
\hline $\begin{array}{l}\text { Mean knowledge } \\
\text { score (standard } \\
\text { deviation) }\end{array}$ & $5.9(1.6)$ & $6.2(1.5)$ & $0.327^{*}$ \\
\hline \multicolumn{4}{|c|}{ Perceptions toward antimicrobial resistance } \\
\hline $\begin{array}{l}\text { Antibiotic resistance is } \\
\text { not a serious problem } \\
\text { because new } \\
\text { antibiotics will be } \\
\text { developed to replace } \\
\text { resistant ones }\end{array}$ & $4.5(1-5)$ & $5(2-5)$ & $0.019 *$ \\
\hline $\begin{array}{l}\text { Antibiotic resistance is } \\
\text { a global public health } \\
\text { problem }\end{array}$ & $5.0(1-5)$ & $5.0(1-5)$ & $0.027^{*}$ \\
\hline $\begin{array}{l}\text { The problem of } \\
\text { antibiotic resistance is } \\
\text { over-rated }\end{array}$ & $4.0(1-5)$ & $4.0(1-5)$ & $0.002 *$ \\
\hline $\begin{array}{l}\text { I need more training } \\
\text { on antibiotic } \\
\text { resistance }\end{array}$ & $5.0(1-5)$ & $5.0(3-5)$ & $0.526 *$ \\
\hline $\begin{array}{l}\text { Strong knowledge of } \\
\text { antibiotic resistance is } \\
\text { important in their } \\
\text { pharmacy career }\end{array}$ & $5.0(2-5)$ & $5.0(3-5)$ & $0.460 *$ \\
\hline $\begin{array}{l}\text { Total median } \\
\text { perception score (IQR) }\end{array}$ & $22.5(12-25)$ & $23(16-25)$ & $0.008^{*}$ \\
\hline
\end{tabular}


Table III: Knowledge of antibiotic therapy among final year pharmacy students

\begin{tabular}{|c|c|c|c|}
\hline \multirow[t]{2}{*}{ Variable } & \multicolumn{2}{|c|}{$\begin{array}{c}\text { Correct response } \\
(\%)\end{array}$} & \multirow[t]{2}{*}{$\begin{array}{l}p \text { - } \\
\text { value }\end{array}$} \\
\hline & $\begin{array}{l}\text { Nigeria } \\
(n=63)\end{array}$ & $\begin{array}{c}\text { Malaysia } \\
(n=87)\end{array}$ & \\
\hline $\begin{array}{l}\text { Recognise diarrhea with no } \\
\text { indication for antibiotic } \\
\text { therapy }\end{array}$ & $32(50.8)$ & $74(85.1)$ & $<0.001$ \\
\hline $\begin{array}{l}\text { Recognise upper respiratory } \\
\text { tract infection with potentially } \\
\text { unnecessary antibiotic }\end{array}$ & 7 (11.1) & $12(13.8)$ & 0.804 \\
\hline $\begin{array}{l}\text { Select appropriate antibiotic } \\
\text { for Clostridium difficile colitis }\end{array}$ & $35(55.6)$ & $43(49.4)$ & 0.510 \\
\hline $\begin{array}{l}\text { Identify antibiotic that is safe } \\
\text { during pregnancy }\end{array}$ & $50(79.4)$ & 73 (83.9) & 0.522 \\
\hline $\begin{array}{l}\text { Select antibiotic with the best } \\
\text { activity against anaerobes }\end{array}$ & $24(38.1)$ & $49(56.3)$ & 0.032 \\
\hline $\begin{array}{l}\text { Select antibiotic that is } \\
\text { effective against Methicillin } \\
\text { resistant Staphylococcus } \\
\text { aureus (MRSA) }\end{array}$ & $25(39.7)$ & $79(90.8)$ & $<0.001$ \\
\hline $\begin{array}{l}\text { Identify antibiotic that crosses } \\
\text { the blood-brain barrier }\end{array}$ & $30(47.6)$ & $56(64.4)$ & 0.046 \\
\hline $\begin{array}{l}\text { Identify single daily dosing of } \\
\text { aminoglycosides such as } \\
\text { gentamicin }\end{array}$ & $21(33.3)$ & 33 (37.9) & 0.608 \\
\hline $\begin{array}{l}\text { Select appropriate surgical } \\
\text { antibiotic prophylaxis for } \\
\text { caesarean section }\end{array}$ & $6(9.5)$ & $29(33.3)$ & 0.001 \\
\hline $\begin{array}{l}\text { Select appropriate antibiotics } \\
\text { for uncomplicated urinary tract } \\
\text { infection }\end{array}$ & $35(55.6)$ & $23(26.4)$ & $<0.001$ \\
\hline $\begin{array}{l}\text { Mean knowledge score } \\
\text { (standard deviation) }\end{array}$ & $4.2(1.8)$ & $5.4(1.8)$ & $<0.001 *$ \\
\hline
\end{tabular}

\section{Knowledge and perceptions toward antimicrobial stewardship}

The result showed that $47.6 \%$ and $43.7 \%$ of the students had received formal training in antimicrobial stewardship in Nigeria and Malaysia, respectively. The Majority (more than $85 \%$ ) of the students indicated that they need more training in antimicrobial therapy and antimicrobial stewardship. There was no difference in the knowledge of the goals of antimicrobial stewardship $(65.1 \%$ and $79.3 \%)$, members of the antimicrobial stewardship team (81.0\% and $88.5 \%)$, types of antimicrobial stewardship interventions (77.8\% and $77.0 \%)$, and the roles of pharmacists in antimicrobial stewardship (76.2\% and $71.3 \%$ ) between the Nigerian students and the Malaysian students, respectively. Overall, the mean knowledge score for antimicrobial stewardship was $3.3 \pm 1.3$ (maximum score 5.0) among the Nigerian students and $3.6 \pm 1.2$ among the Malaysian students $(p=0.130)$. The details of knowledge and perceptions toward antimicrobial stewardship are shown in Table IV.
Table IV: Knowledge and perceptions toward antimicrobial stewardship among the students

\begin{tabular}{|c|c|c|c|}
\hline \multirow[b]{2}{*}{ Variable } & \multicolumn{2}{|c|}{ Correct responses (\%) } & \multirow[t]{2}{*}{$p$-value } \\
\hline & $\begin{array}{l}\text { Nigeria } \\
(n=63)\end{array}$ & $\begin{array}{c}\text { Malaysia } \\
(\mathrm{n}=87)\end{array}$ & \\
\hline $\begin{array}{l}\text { Formal training in } \\
\text { antimicrobial } \\
\text { stewardship }\end{array}$ & $30(47.6)$ & $38(43.7)$ & $<0.001^{*}$ \\
\hline \multicolumn{4}{|c|}{ Rating of knowledge on antimicrobial stewardship } \\
\hline - Poor & $15(23.8)$ & $43(49.4)$ & $<0.001^{\dagger}$ \\
\hline - Average & $32(50.8)$ & $41(47.1)$ & \\
\hline - Good & $9(14.3)$ & $1(1.1)$ & \\
\hline - Very good & $5(7.9)$ & $2(2.3)$ & \\
\hline $\begin{array}{l}\text { I would like more training } \\
\text { on the appropriate use of } \\
\text { antibiotics }\end{array}$ & $55(87.3)$ & $84(96.6)$ & $0.181^{\dagger}$ \\
\hline $\begin{array}{l}\text { I would like more training } \\
\text { on antimicrobial } \\
\text { stewardship }\end{array}$ & $54(85.7)$ & $83(95.4)$ & $0.622^{\dagger}$ \\
\hline \multicolumn{4}{|c|}{ Knowledge of antimicrobial stewardship } \\
\hline $\begin{array}{l}\text { Identify goals of } \\
\text { antimicrobial } \\
\text { stewardship programme }\end{array}$ & $41(65.1)$ & $69(79.3)$ & $0.062 *$ \\
\hline $\begin{array}{l}\text { Recognise members of } \\
\text { antimicrobial } \\
\text { stewardship team }\end{array}$ & $51(81.0)$ & $77(88.5)$ & $0.244^{*}$ \\
\hline $\begin{array}{l}\text { Identify antimicrobial } \\
\text { stewardship } \\
\text { interventions }\end{array}$ & $49(77.8)$ & $67(77.0)$ & $1.000 *$ \\
\hline $\begin{array}{l}\text { Understands the role of } \\
\text { the pharmacist in the } \\
\text { antimicrobial } \\
\text { stewardship team }\end{array}$ & $48(76.2)$ & $62(71.3)$ & $0.576^{*}$ \\
\hline $\begin{array}{l}\text { Identify setting where } \\
\text { antimicrobial } \\
\text { stewardship programme } \\
\text { is not required }\end{array}$ & $21(33.3)$ & $43(49.4)$ & $0.066^{*}$ \\
\hline $\begin{array}{l}\text { Mean knowledge score } \\
\text { (standard deviation) }\end{array}$ & $3.3(1.3)$ & $3.6(1.2)$ & $0.130 *$ \\
\hline
\end{tabular}

\section{Confidence of the respondents to participate in antimicrobial stewardship activities}

The Nigerian students demonstrated higher confidence to diagnose infection/sepsis (median 3.0, IQR 1 - 5), identify an infection that does not require antimicrobial therapy (median 3.0, $1-5$ ) and choose appropriate empirical therapy (median 3.0, IQR $1-5$ ) compared to Malaysian students who scored medians (IQR) of 2.0, 1 $-5 ; 2.0,1-5$; and 2.0,1-5, respectively. Also, Nigerian students had significantly higher scores for selecting the appropriate duration of therapy and de-escalation (median 3.0, IQR 1 - 5) than the Malaysian students (median 2.0, IQR 1 - 5) $p<0.001$. Overall, the total median confidence score was higher among the Nigerian students (median 48.0, IQR 26-75) compared to Malaysian students (median 36.5, IQR $15-75$ ), $p<$ 0.001 (Table V). 
Table V: Confidence to participate in antimicrobial stewardship activities

\begin{tabular}{|c|c|c|}
\hline \multirow[t]{2}{*}{ Variable } & \multicolumn{2}{|c|}{$\begin{array}{l}\text { Median confidence score } \\
\text { (IQR) }\end{array}$} \\
\hline & $\begin{array}{l}\text { Nigeria } \\
(n=63)\end{array}$ & $\begin{array}{c}\text { Malaysia } \\
\text { (n= 87) }\end{array}$ \\
\hline $\begin{array}{l}\text { Make accurate diagnosis of } \\
\text { infection/sepsis }\end{array}$ & $3.0(1-5)$ & $2.0(1-5)$ \\
\hline $\begin{array}{l}\text { Identify infection that do not } \\
\text { require antibiotic therapy }\end{array}$ & $3.0(1-5)$ & $2.5(1-5)$ \\
\hline $\begin{array}{l}\text { Choose appropriate } \\
\text { empirical therapy }\end{array}$ & $3.0(1-5)$ & $2.0(1-5)$ \\
\hline $\begin{array}{l}\text { Interpret microbiological } \\
\text { result }\end{array}$ & $3.0(1-5)$ & $3.0(1-5)$ \\
\hline $\begin{array}{l}\text { Choose antibiotic } \\
\text { combinations where } \\
\text { appropriate }\end{array}$ & $3.0(1-5)$ & $2.0(1-5)$ \\
\hline $\begin{array}{l}\text { Choose between intravenous } \\
\text { and oral administration }\end{array}$ & $3.0(2-5)$ & $3.0(1-5)$ \\
\hline $\begin{array}{l}\text { Choose the correct dose of } \\
\text { antibiotics }\end{array}$ & $3.0(1-5)$ & $2.0(1-5)$ \\
\hline $\begin{array}{l}\text { Choose appropriate dosage } \\
\text { interval/frequency }\end{array}$ & $3.0(1-5)$ & $2.0(1-5)$ \\
\hline $\begin{array}{l}\text { Interpret the result of } \\
\text { Therapeutic Drug Monitoring } \\
\text { and making } \\
\text { recommendations }\end{array}$ & $3.0(1-5)$ & $3.0(1-5)$ \\
\hline $\begin{array}{l}\text { Choose appropriate duration } \\
\text { of treatment }\end{array}$ & $3.0(1-5)$ & $2.0(1-5)$ \\
\hline $\begin{array}{l}\text { Plan streamline or } \\
\text { deescalate antibiotic therapy }\end{array}$ & $3.0(1-5)$ & $2.0(1-5)$ \\
\hline $\begin{array}{l}\text { Describe the correct } \\
\text { spectrum of antimicrobial } \\
\text { therapy for different } \\
\text { antibiotics (what is covered } \\
\text { by each drug) }\end{array}$ & $3.0(1-5)$ & $2.0(1-5)$ \\
\hline $\begin{array}{l}\text { Understand the basic } \\
\text { mechanisms of antibiotic } \\
\text { resistance }\end{array}$ & $3.0(1-5)$ & $3.0(1-5)$ \\
\hline $\begin{array}{l}\text { Find reliable sources of } \\
\text { information to treat } \\
\text { infections }\end{array}$ & $3.0(1-5)$ & $3.0(1-5)$ \\
\hline $\begin{array}{l}\text { Monitor efficacy and safety } \\
\text { of the chosen antibiotic } \\
\text { therapy }\end{array}$ & $3.0(1-5)$ & $3.0(1-5)$ \\
\hline $\begin{array}{l}\text { Median (IQR) confidence } \\
\text { score }\end{array}$ & $48.0(26-75)$ & $36.5(15-75)^{*}$ \\
\hline
\end{tabular}

\section{Discussion}

The current study found that interest in infectious diseases (ID) pharmacy was higher among Nigerian pharmacy students; the attendance of a workshop/course on antimicrobial therapy and attendance of ID clerkship was significantly lower compared to the Malaysian pharmacy students. This could be explained by the differences in pharmacy training curricula used in the two countries. Pharmacy training in Nigeria appears to be more theory-oriented as pharmacy students receive experiential training for only one semester (in the first semester of their final year). In Malaysia, pharmacy students are exposed to experiential learning for at least three semesters before graduation. It was also found that pharmacy students in Malaysia have a significantly higher knowledge of antimicrobial therapy compared to those in Nigeria, and this could be attributed to the higher ID clerkship experience among pharmacy students in Malaysia. To strengthen this view, a previous study demonstrated that pharmacy students who attended ID clerkship have a higher knowledge of antimicrobial therapy (Abubakar et al., 2020). These observations highlight the need to increase experiential training among pharmacy students in Nigeria.

Lack of knowledge has been identified as a significant barrier to hospital and community pharmacists' participation in AMS activities (Weier et al., 2018; Abubakar, 2020; Abubakar \& Tangiisuran, 2020). Similarly, most of the students in the current study indicated that they need more training in antimicrobial resistance, antimicrobial therapy, and antimicrobial stewardship, consistent with previous studies conducted among pharmacy students (Justo et al., 2014; Abubakar et al., 2020). Overall, the students had moderate knowledge of antimicrobial resistance, similar to an earlier study (Abubakar et al., 2020). Knowledge of antimicrobial resistance was comparable between the two groups of pharmacy students. In both groups, knowledge of the reservoirs of antimicrobial resistance, as well as implications and factors that contribute to the dissemination of antimicrobial resistance, was poor. These observations indicate areas of antimicrobial resistance in which additional training is required to improve the competence of future pharmacists. The current study also revealed that pharmacy students in Malaysia had a better positive perception of antimicrobial resistance compared to those in Nigeria. The reason for this difference could be attributed to a difference in exposure to experiential learning between the two groups.

Misuse of antimicrobials in patients with upper respiratory tract infection (URTI) in both community and hospital settings is one of the potential targets for AMS (Auta et al., 2018; Tham et al., 2020). The current study found that pharmacy students had good knowledge of diarrhoea (that does not require antimicrobial therapy) but a poor understanding of URTI that lacks indication for antimicrobial therapy. This was consistent with previous studies conducted among pharmacy students in the United States and Asia, including Malaysian students (Justo et al., 2014; Abubakar et al., 2020;). The overuse of surgical antimicrobial prophylaxis is another area that has been identified for the implementation of AMS (Abubakar et al., 2018; Abubakar, 2020). It was found that more than 
two-thirds of the students had poor knowledge of surgical antimicrobial prophylaxis. Besides, there was also poor knowledge of antimicrobial therapy for uncomplicated urinary tract infections among the students. Additional training is recommended for pharmacy undergraduate students, particularly in the areas of identification of infections that do not require antimicrobial therapy, surgical antimicrobial prophylaxis, and antimicrobial selection for the treatment of various infections. This is important because early carrier pharmacists are more likely to dispense antimicrobials inappropriately (Abubakar \& Tangiisuran, 2020). Practising pharmacists have identified the lack of knowledge as a major barrier to their involvement in AMS activities (Abubakar, 2020; Abubakar \& Tangiisuran, 2020). In the current study, more than half of the students had no formal training in AMS, in consonance with a previous study conducted in South Africa (Burger et al., 2016). Pharmacists have an essential role to play in the development and implementation of the AMS programme (Wickens et al., 2013; CDC, 2014; Pollack \& Srinivasan, 2014). Therefore, the inclusion of AMS in the undergraduate training curriculum is recommended to build competency and confidence among future pharmacists to enable them to participate in AMS activities.

Overall, pharmacy students have a moderate level of self-confidence to complete AMS tasks, and moderate confidence was observed in all the AMS tasks except for the diagnosis of infection/sepsis and the de-escalation of antimicrobial therapy. The lack of high confidence in AMS activities may be explained by the lack of formal training in AMS among most pharmacy students. The current study found that about one-third of the final year students do not have confidence (not very confident/not confident at all) to identify an infection that does not need antimicrobial therapy and select an appropriate antimicrobial regimen (empirical choice, dose, frequency, and duration). This finding highlights the need for more didactic and experiential training among pharmacy students to improve their skills and confidence to participate in AMS activities. It is crucial for pharmacists to identify the signs and symptoms of infections confidently and to distinguish between an infection that needs antimicrobial therapy and those with no indication for antimicrobial therapy to reduce inappropriate dispensing of antimicrobials. This is particularly important in a community pharmacy setting where inappropriate dispensing of antimicrobials is reported among patients with infections such as upper respiratory tract infection (Auta et al., 2018). Self-reported confidence to complete AMS activities was higher among pharmacy students in Nigeria compared to those in Malaysia. The reason for this difference is unclear but could be attributed to the higher formal training in AMS among Nigerian students. Additional studies are required to validate the results of this study and to explain the difference in self-reported confidence among pharmacy students.

This study has some limitations and should be interpreted with caution. Firstly, the research was conducted in one pharmacy school, each in Malaysia and Nigeria, and therefore findings are not generalizable. Secondly, confidence was measured using a self-reported scale, and the responses are susceptible to social desirability bias. This could be avoided by assessing confidence in a clinical setting in the form of an objective structured clinical examination. Thirdly, the items used to evaluate the knowledge of antimicrobial resistance and antimicrobial therapy may not cover all the topics and thus could introduce an assessment bias. Fourthly, some of the items in the questionnaire require students to recall previous information, and the responses are liable to recall bias. Despite these limitations, the current study provides an insight into the knowledge and self-confidence among final year pharmacy undergraduate students in Malaysia and Nigeria to participate in AMS. The results indicate the need for more training and exposure to experiential learning to improve the knowledge and self-confidence to participate in antimicrobial stewardship programmes considering that the students are nearly early practitioners. Future studies should encapsulate the limitations highlighted in this study.

\section{Conclusion}

The final year pharmacy undergraduate students in Malaysia and Nigeria have appreciable knowledge and perceptions towards antimicrobial resistance. The students have a moderate knowledge of antimicrobial therapy, with higher knowledge scores among the Malaysian students. Also, there was a moderate level of self-confidence to participate in the antimicrobial stewardship programme among the students, with higher confidence observed among the Nigerian students. Exposure to experiential learning in the form of infectious diseases clerkship has an impact on the knowledge of antimicrobial resistance and antimicrobial stewardship among undergraduate pharmacy students. About one in three final year students lack the confidence to select appropriate antimicrobial regimens. Pharmacy students need more training in antimicrobial resistance, antimicrobial therapy, and antimicrobial stewardship to improve their knowledge and confidence to participate in antimicrobial stewardship. 


\section{References}

Ab Rahman, N., Teng, C. L., \& Sivasampu, S. (2016). Antibiotic prescribing in public and private practice: a cross-sectional study in primary care clinics in Malaysia. BMC infectious diseases, 16(1), 208. https://doi.org/10.1186/s12879-016-15302

Abubakar, U. (2020). Practices and perceptions of Nigerian community pharmacists toward antimicrobial stewardship program. International Journal of Pharmacy and Pharmaceutical Sciences, 12(4), 37-42. https://doi.org/10.22159/ijpps.2020v12i4.36505

Abubakar, U. (2020). Antibiotic use among hospitalized patients in northern Nigeria: a multicenter point-prevalence survey. BMC Infectious Diseases, 20(1), 86. https://doi.org/10.1186/s12879020-4815-4

Abubakar, U., \& Tangiisuran, B. (2020). Knowledge and practices of community pharmacists towards non-prescription dispensing of antibiotics in Northern Nigeria. International journal of clinical pharmacy, 1-9. https://doi.org/10.1007/s11096-020-01019-y

Abubakar, U., \& Tangiisuran, B. (2020). Nationwide survey of pharmacists' involvement in antimicrobial stewardship programs in Nigerian tertiary hospitals. Journal of global antimicrobial resistance, 21, 148-153. https://doi.org/10.1016/j.jgar.2019.10.007

Abubakar, U., Muhammad, H. T., Sulaiman, S. A. S., Ramatillah, D. L., \& Amir, O. (2020). Knowledge and selfconfidence of antibiotic resistance, appropriate antibiotic therapy, and antibiotic stewardship among pharmacy undergraduate students in three Asian countries. Currents in Pharmacy Teaching and Learning. https://doi.org/10.1016/j.cptl.2019.12.002

Abubakar, U., Sulaiman, S. S., \& Adesiyun, A. G. (2018). Utilization of surgical antibiotic prophylaxis for obstetrics and gynaecology surgeries in Northern Nigeria. International journal of clinical pharmacy, 40(5), 1037-1043. https://doi.org/10.1007/s11096018-0702-0

Abubakar, U., Syed Sulaiman, S. A., \& Adesiyun, A. G. (2019). Impact of pharmacist-led antibiotic stewardship interventions on compliance with surgical antibiotic prophylaxis in obstetric and gynecologic surgeries in Nigeria. PloS one, 14(3), e0213395. https://doi.org/10.1371/journal.pone.0213395

Auta, A., Hadi, M. A., Oga, E., Adewuyi, E. O., Abdu-Aguye, S. N., Adeloye, D., ... \& Morgan, D. J. (2019). Global access to antibiotics without prescription in community pharmacies: A systematic review and meta-analysis. Journal of Infection, 78(1), 8-18. https://doi.org/10.1016/j.jinf.2018.07.001

Brink, A. J., Messina, A. P., Feldman, C., Richards, G. A., Becker, P. J., Goff, D. A., ... \& Alliance, N. A. S. S. (2016). Antimicrobial stewardship across 47 South African hospitals: an implementation study. The Lancet Infectious Diseases, 16(9), 1017-1025. https://doi.org/10.1016/S1473-3099(16)30012-3

Burger, M., Fourie, J., Loots, D., Mnisi, T., Schellack, N., Bezuidenhout, S., \& Meyer, J. C. (2016). Knowledge and perceptions of antimicrobial stewardship concepts among final year pharmacy students in pharmacy schools across South Africa. Southern African Journal of Infectious Diseases, 31(3), 8490. https://doi.org/10.1080/23120053.2016.1192808
Centers for Disease Control and Prevention. (2017). Core elements of hospital antibiotic stewardship programs. Atlanta, GA: US Department of Health and Human Services, CDC; 2014

European Centre for Disease Prevention and Control \& European Medicines Agency. The Bacterial Challenge: Time to React-A Call to Narrow the Gap between Multidrug-Resistant Bacteria in the EU and the Development of New Antibacterial Agents. ECDC/EMEA Joint Technical report. 2009

Justo, J. A., Gauthier, T. P., Scheetz, M. H., Chahine, E. B., Bookstaver, P. B., Gallagher, J. C., ... \& Esterly, J. S. (2014). Knowledge and attitudes of doctor of pharmacy students regarding the appropriate use of antimicrobials. Clinical Infectious Diseases, 59(suppl_3), S162-S169. https://doi.org/10.1093/cid/ciu537

Pollack, L. A., \& Srinivasan, A. (2014). Core elements of hospital antibiotic stewardship programs from the Centers for Disease Control and Prevention. Clinical Infectious Diseases, 59(suppl_3), S97-S100. https://doi.org/10.1093/cid/ciu542

Ponto, J. A. (2010). ASHP statement on the pharmacist's role in antimicrobial stewardship and infection prevention and control. Am J Health Syst Pharm, 67, 575. https://doi.org/10.2146/sp100001

Rizvi, T., Thompson, A., Williams, M., \& Zaidi, S. T. R. (2018). Perceptions and current practices of community pharmacists regarding antimicrobial stewardship in Tasmania. International journal of clinical pharmacy, 40(5), 1380-1387. https://doi.org/10.1007/s11096-018-0701-1

Tham, D. W. J., Abubakar, U., \& Tangiisuran, B. (2020). Prevalence and predictors of antibiotic use among children visiting the Emergency Department in a Tertiary Hospital in Malaysia. European Journal of Pediatrics, 1-6. https://doi.org/10.1007/s00431-019-03560-z

US Department of Health and Human Services. Antibiotic resistance threats in the United States. Centers for Disease Control and Prevention. (2013). Available at: https://www.cdc.gov/drugresistance/pdf/ar-threats-2013508.pdf

Wang, J., Dong, M., Lu, Y., Zhao, X., Li, X., \& Wen, A. (2015). Impact of pharmacist interventions on rational prophylactic antibiotic use and cost saving in elective cesarean section. International Journal of Clinical Pharmacology and Therapeutics, 53(8), 605-15. https://doi.org/10.5414/CP202334

Weier, N., Tebano, G., Thilly, N., Demoré, B., Pulcini, C., \& Zaidi, S. T. R. (2018). Pharmacist participation in antimicrobial stewardship in Australian and French hospitals: a cross-sectional nationwide survey. Journal of Antimicrobial Chemotherapy, 73(3), 804-813. https://doi.org/10.1093/jac/dkx435

Wickens, H. J., Farrell, S., Ashiru-Oredope, D. A. I., Jacklin, A., Holmes, A., Antimicrobial Stewardship Group of the Department of Health Advisory Committee on Antimicrobial Resistance and Health Care-Associated Infections (ASG-ARHAI), ... \& Dryden, M. (2013). The increasing role of pharmacists in antimicrobial stewardship in English hospitals. Journal of Antimicrobial Chemotherapy, 68(11), https://doi.org/10.1093/jac/dkt241

2675-2681.

World Health Organization. (2014). Antimicrobial resistance: global report on surveillance. World Health Organization 